\title{
Urdimento
}

Revista de Estudos em Artes Cênicas

E-ISSN: 2358.6958

\section{Ação em Combate: Criação colaborativa, participação e transcriação no processo criativo}

Fernanda Vieira Fernandes

Maria Amélia Gimmler Netto

\section{Para citar este artigo:}

FERNANDES, Fernanda Vieira; GIMMLER NETTO, Maria Amélia. Ação em Combate: Criação colaborativa, participação e transcriação no processo criativo. Urdimento, Florianópolis, v. 3, n. 39, nov./dez. 2020.

DOI: http:/dx.doi.org/10.5965/14145731033920200208

Este artigo passou pelo Plagiarism Detection Software | iThenticate 
Ação em Combate: Criação colaborativa, participação e transcriação no processo criativo

Fernanda Vieira Fernandes

Maria Amélia Gimmler Netto²

\title{
Resumo
}

Este artigo discute a criação colaborativa do espetáculo Combate: corpos mortos, vivos e por vir. A montagem problematizou o machismo e o racismo, envolveu docentes, licenciandos em teatro e artistas locais de Pelotas, no extremo sul do Brasil. Apresentam-se aqui aspectos da pesquisa em artes cênicas e dos processos práticos de criação da encenação e escrita dramática na contemporaneidade, valendo-se dos referenciais de Béatrice Picon-Vallin e Antônio Araújo sobre criação colaborativa, de Óscar Cornago sobre participação, e de Haroldo de Campos sobre transcriação.

Palavras-chave: Encenação. Escrita dramática. Criação colaborativa. Participação. Transcriação.

Action in Combate: Collaborative creation, participation and transcreation in the creative process

\begin{abstract}
This article discusses the creation of the play Combate: corpos mortos, vivos e por vir. The staging problematized sexism and racism and the work involved professors, drama graduate students and local artists. It was produced by means of a collaborative creation process in the extreme South of Brazil. Here are presented some aspects of research in performing arts and also those related to the practical creative processes of staging and dramatic writing in contemporaneity. Béatrice Picon-Vallin and Antônio Araújo were the references for the idea of collaborative creation, Oscar Cornago for the notion of participation and, finally, Haroldo de Campos for the concept of transcreation.
\end{abstract}

Keywords: Staging. Dramatic writing. Collaborative creation. Participation. Transcreation.

\footnotetext{
Atriz, dramaturgista, pesquisadora e professora do Curso de Teatro-Licenciatura do Centro de Artes, da Universidade Federal de Pelotas (UFPel). Doutora e Mestre em Letras pelo PPGLET/UFRGS, com bolsa CAPES de doutorado-sanduíche na Paris 3 - Sorbonne Nouvelle. Bacharel em Artes Cênicas com ênfase em Interpretação Teatral pelo DAD/UFRGS. Realizou Pós-doutorado no laboratório SeFeA ("Scènes francophones et écritures de l'altérité”), da Paris 3 - Sorbonne Nouvelle (2019).nvnandes@gmail.com

2 Artista cênica e professora do Curso de Teatro-Licenciatura do Centro de Artes, Universidade Federal de Pelotas (UFPel). Doutoranda em Artes Cênicas pelo PPGAC/UFBA com doutorado sanduíche no Centro de Ciencias Humanas y Sociales del Consejo Superior de Investigaciones Científicas, Madrid/España. Mestre em Artes Cênicas pelo PPGAC/UFRGS e licenciada em Educação Artística-Habilitação em Artes Cênicas pelo CEART/UDESC. O presente artigo foi escrito no período em que a autora recebeu financiamento de bolsa de estudos pela Coordenação de Aperfeiçoamento de Pessoal de Nível Superior - Brasil (Capes), no âmbito do Programa Capes-PrInt, processo no 88887.364898/2019-00. mamelianetto@gmail.com maria.amelia@ufpel.br
} 
Combat Action: Creación colaborativa, participación y transcreación en el proceso creativo

\section{Resumen}

Este artículo analiza la creación colaborativa del espectáculo Combate: corpos mortos, vivos e por vir. La obra problematizó el machismo y el racismo e implicó la participación de estudiantes, profesoras y artistas locales de Pelotas, ciudad ubicada en el extremo sur de Brasil. Aquí se presentan aspectos de la investigación en las artes escénicas y los procesos prácticos de creación de la puesta en escena y de la escritura dramática en la época contemporánea, a partir de las referencias de Béatrice Picon-Vallin y Antônio Araújo acerca la creación colaborativa, Óscar Cornago acerca de la participación y Haroldo de Campos sobre la transcreación.

Palabras clave: Puesta en escena. Escritura dramática. Creación colaborativa. Participación. Transcreación. 


\section{Os objetos deste artigo}

Apresenta-se aqui o relato da direção e dramaturgia do trabalho - Combate: corpos mortos, vivos e por vir, uma experiência cênica atual que dialoga com embates sociais de uma época imersa em conflitos ideológicos e políticos que ameaçam a democracia brasileira em seus princípios básicos, como os direitos humanos, as relações de trabalho e o respeito à diversidade. O enfoque principal identificado pelo coletivo foi o combate ao racismo e ao machismo, opressões sociais que atravessam as realidades das pessoas envolvidas, direta ou indiretamente. A proposta foi conduzida pelas professoras Fernanda Vieira Fernandes e Maria Amélia Gimmler Netto, da Universidade Federal de Pelotas, na região sul do Rio Grande do Sul, e estava vinculada a dois projetos de pesquisa coordenados pelas mesmas, que se articulavam no Laboratório de Dramaturgismo e Direção rotativa de cenas, sobre os quais será comentado posteriormente. A experiência cênica contou com a participação de estudantes do Curso de TeatroLicenciatura do Centro de Artes, além de artistas locais. ${ }^{3}$

Um dos impulsos iniciais foi o desejo de trabalhar com a obra Combate de negro e de cães (1979), de Bernard-Marie Koltès, na qual o dramaturgo - homem, branco e europeu - discute tais questões de opressão vivenciadas pelo Outro - a mulher e o negro. Somou-se a esse impulso a intenção de realizar uma experiência de montagem baseada na direção rotativa de cenas. Os trabalhos de escrita do texto dramático e encenação passaram a ser elaborados imediatamente após a formação da equipe, que contou, inicialmente, com nove artistas, mulheres e homens brancos e negros oriundos de diferentes regiões do Brasil, com seus

${ }^{3}$ O elenco de estreia em outubro de 2016 era composto por: Juliana Caroline da Silva, Marco Antônio Duarte, Johann Ossanes, Mario Celso Pereira Junior, Lucas Galho, Gabrielle Winck, Fernanda Vieira Fernandes e Maria Amélia Gimmler Netto. A equipe do processo de criação contou ainda com a participação de Tatiana Duarte. Contribuíram no preparo musical do elenco Gab Mesquita e Fernanda Miki. A temporada de outubro de 2017 contou com o seguinte elenco: Mario Celso Pereira Junior, Fernanda Vieira Fernandes, Lucas Galho, Thairone Dorneles, Cibele Fernandes, Airton Marino e Ana Paula Melo. Foram realizadas apresentações no Casarão 8 - Museu do Doce, em Pelotas/RS, e Theatro Esperança, em Jaguarão/RS. Houve uma ainda uma apresentação da montagem durante seu processo de criação, intitulada Percurso Combate, em junho de 2016, na Fábrica Cultural, na programação do Festival Sete ao Entardecer, da Secretaria de Cultura de Pelotas. 
distintos corpos, vozes e experiências pessoais.

A proposta de combate, como contestação e luta, realizada na obra teatral problematizada neste artigo e desenvolvida por seus artistas, é o antirracismo e o antimachismo. Buscou-se criar ações que mostrassem o lugar da mulher e do negro em nossa sociedade e a hostilidade nas relações humanas que estas pessoas precisam enfrentar em seu cotidiano. As bases de diálogo de Combate foram o referido texto dramático de Koltès e poemas da pelotense Angélica Freitas publicados no livro Um útero é do tamanho de um punho (2013), acrescidos de testemunhos dos participantes, canções, pontos de umbanda, filmes, fatos históricos, dados estatísticos e notícias sobre a violência contra mulheres e pessoas negras.

De que forma o processo, com sua potência de contestação, foi conduzido para se chegar até Combate? Quais soluções cênicas foram usadas para criar uma obra teatral que se assume antirracista e antimachista? Em tempos de crise da democracia, que pode sim ser observada em diversos países, mas que no Brasil vem tomando proporções alarmantes nos últimos anos, que ações podem ser feitas para compreendermos melhor o lugar e o contexto social e político do teatro na atualidade?

O norteador temático deste artigo é o trabalho colaborativo de criação, com enfoque nos processos de dramaturgismo e de encenação. Problematiza-se, para tanto, a noção de colaboração na criação cênica, valendo-se dos referenciais de Béatrice Picon-Vallin e Antônio Araújo, faz-se uma descrição da prática da direção rotativa de cenas e do dramaturgismo desenvolvido em Combate e apresenta-se uma reflexão acerca das ideias de transcriação, sob o prisma de Haroldo de Campos e de participação nas artes cênicas, com ideias de Óscar Cornago.

\section{Transcriação e dramaturgismo: o processo da escrita dramática}

O processo de escrita do texto final levado à cena em combate: corpos mortos, vivos e por vir aliou dois conceitos principais em seu processo de composição: o dramaturgismo e a transcriação. Vinculada ao projeto: "Poética, 
concepção e composição da escrita dramática no Laboratório de Dramaturgismo e Direção rotativa de cenas", a pesquisa coordenada por Fernanda Vieira Fernandes buscava, entre outros objetivos, refletir sobre formas possíveis de inserção da dramaturgista no trabalho de prática teatral marcada pelo processo colaborativo, concebendo a poética e a escrita dramática num esquema de retroalimentação. Ao mesmo tempo em que Fernandes trazia elementos para o jogo entre atrizes, atores, diretoras e diretores rotativos, estes the forneciam materiais para compor um texto dramático final que seria apresentado na montagem. A participação da dramaturgista se deu desde o primeiro encontro e se perpetuou na sala de ensaio.

A figura do dramaturgista surgiu no teatro ocidental na Alemanha do século XVIII, com G. E. Lessing, designado dramaturg, diferenciando-se do dramatiker(em português, dramaturgo), a pessoa que escrevia a peça em gabinete. Patrice Pavis (2003) define o dramaturgista como uma espécie de conselheiro literário e teatral de um grupo, elencando algumas das atividades executadas por essa figura, tais como escolher as peças em função de sua atualidade, combinar textos escolhidos para a encenação, realizar pesquisas sobre a(s) obra(s), intervir eventualmente durante os ensaios como um observador crítico e adaptar ou modificar o(s) texto(s) com colagens, supressões etc.

Portanto, ao acompanhar o processo como um todo, o dramaturgista leva em consideração diversos aspectos relacionados à criação de uma encenação e seu texto é resultado disso. No caso do laboratório, a opção por esse tipo de escrita dramática atendia a alguns dos questionamentos que guiavam a pesquisa acadêmica por trás da montagem: como estimular um ambiente interessante à criação cênica a partir da literatura dramática ou de outros recursos que servissem à improvisação? Como engajar esses artistas nas questões políticas que atravessavam o processo de encenação? Como despertar a reflexão sobre o machismo e o racismo no cotidiano em que estavam inseridos? Uma das ferramentas foi incentivar que escrevessem, que trouxessem suas impressões, memórias, inquietações e sensações.

O dramaturgismo se deu, então, pela coleta de materiais que se modificaram e fizeram nascer uma nova dramaturgia, que dialogava com a realidade do grupo. 
Na base, estava o referido texto de Koltès. Na obra koltesiana, um operário negro é assassinado pelo engenheiro branco Cal em um canteiro de obras francês de um país africano - o fato caracteriza-se como crime de ódio, motivado pelo racismo. O irmão do operário vai até o local para buscar o corpo, mas este foi jogado no esgoto e é impossível recuperá-lo. O chefe do canteiro, Horn, tenta acobertar o seu colega branco e convencer o homem negro a desistir da busca. Além dessas três figuras masculinas, há uma mulher recentemente chegada ao local para casar-se com o chefe. A opressão aparece tanto com relação ao homem negro, Alboury, quanto à mulher, Léone, tratada como um bibelô pelo chefe, assediada violentamente pelo engenheiro e, num momento final, hostilizada pelo homem negro - ainda que se possa caracterizar alguns dos comportamentos dela como racistas ou de quem não compreende os valores de Alboury.

Koltès coloca em jogo essas quatro pessoas que são incapazes de dialogar e encontrar meios ou acordos, que não conseguem se colocar no espaço do Outro, as quais só resta um combate animalesco. A escrita ocorreu a partir de uma experiência de viagem dele a um canteiro de obras na Nigéria e muitas das situações vistas no texto, partem de relatos e fatos reais. Contudo, conforme já explicitado acima, fazia-se necessário aproximar a temática dessas opressões ao coletivo de jovens artistas criadores. O que este texto dramático escrito no final dos anos de 1970 pode render de discussão para a criação cênica na segunda década do ano 2000 no Brasil? Em que pontos as realidades de opressão, do machismo e do racismo observadas por ele poderiam se tocar com as que atingiam o grupo do laboratório? Que outras escritas, criações e vivências poderiam se articular nesse processo?

Para agregar novos elementos além do texto dramático de base, somaramse as poesias Um útero é do tamanho de um punho e $A$ mulher de vermelho de Angélica Freitas (2013), testemunhos do grupo partindo de perguntas estimuladoras como: "O que te traz conforto e o que te desconforta?", os filmes Dogville(2003) e Manderlay (2005) do dinamarquês Lars Von Trier, dados históricos de pesquisa local de Ester Gutierrez (2001) sobre as charqueadas e olarias do período escravocrata em Pelotas, letras das músicas Volte para o seu lar, de 
Arnaldo Antunes (1998), e Pade Onã, de Kiko Dinucci (2008), pontos de umbanda, dados estatísticos sobre a violência contra mulheres e negros no Brasil, acrescidos de notícias/manchetes veiculadas pela imprensa nacional na atualidade. Todos eles foram transcriados a partir do dramaturgismo.

O conceito de transcriação, elaborado pelo teórico, linguista e tradutor Haroldo de Campos no âmbito das letras, ocupa espaço significativo nos estudos sobre tradução literária. A dificuldade, ou mesmo impossibilidade, como defende Campos, em traduzir um texto e manter sua essência da língua original, é fato notório na transposição para outro idioma, dadas as especificidades linguísticas e singularidades culturais. O resultado de uma tradução literal é esvaziado da riqueza da criatividade. A passagem de uma língua para outra, portanto, vai além do mero exercício linguístico. Ela transcria a obra, comunicando através de outros signos e palavras as imagens e sentimentos expressas originalmente pelo autor:

Admitida a tese da impossibilidade em princípio da tradução de textos criativos, parece-nos que esta engendra o corolário da possibilidade, também em princípio, da recriação desses textos. Teremos, [...], em outra língua, uma outra informação estética, autônoma, mas ambas estarão ligadas entre si por uma relação de isomorfia: serão diferentes enquanto linguagem, mas, como os corpos isomorfos, cristalizar-se-ão de um mesmo sistema. [...] Então, para nós, tradução de textos criativos será sempre recriação, ou criação paralela, autônoma porém recíproca. Quanto mais inçado de dificuldades esse texto, mais recriável, mais sedutor enquanto possibilidade aberta de recriação. Numa tradução dessa natureza, não se traduz apenas o significado, traduz-se o próprio signo, ou seja, sua fisicalidade, sua materialidade mesma [...]. (Campos, 2015, p. 4-5. Grifos do autor).

O conceito de transcriação tem sido ressignificado e usado para compreender movimentos diversos e passagens de uma linguagem para outra. A transposição de uma obra literária para o cinema, por exemplo. Amplia-se, assim, a ideia da transcriação, ao desconstruir uma determinada obra para reconstruí-la em outra abordagem literária ou artística.

O fio condutor de Combate seguia tendo como base a história do homem negro que vem até o espaço dos brancos para buscar o corpo do irmão e a da mulher recém chegada que se confronta com um universo masculino hostil. 
Porém, ao invés do canteiro de obras, a montagem escolheu um dos históricos casarões coloniais pelotenses, resquícios de um tempo escravagista, localizado no centro da cidade. Ali, segundo visita guiada feita sob responsabilidade dos administradores, as mulheres ocupavam durante o dia as salas da frente para seus ensaios de instrumentos musicais ou para costurar e bordar, numa espécie de janela-vitrine para a rua, mas seus quartos não tinham portas de acesso ao lado externo para evitar que recebessem visitas ou que saíssem escondidas - diferente do quarto dos filhos homens, sempre com acesso facilitado ao exterior. O casarão conta também com um porão habitável, em termos arquitetônicos, lugar por onde provavelmente circulavam os escravizados, pessoas cuja mão de obra ergueu a cidade de Pelotas.

A história de Alboury e Léone ganhou outros ares em sua transcriação. A composição final do texto dramático contou com doze cenas, além de prólogo e póslogo. Cada uma delas recebeu um título, conforme segue:

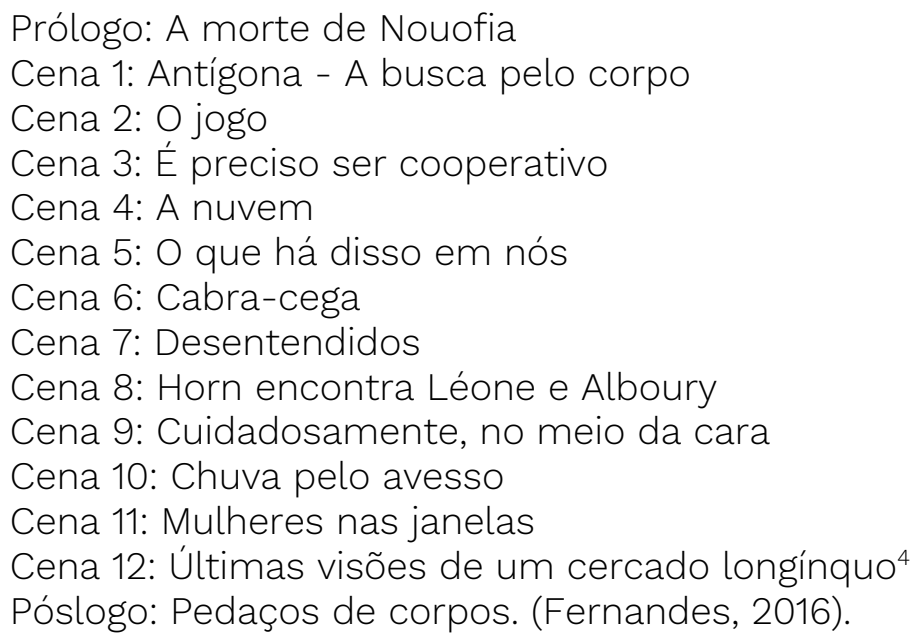

Algumas cenas criadas por Koltès mantiveram, em parte, a estrutura de seus diálogos e personagens presentes, outras diluíram-se com os elementos supracitados e geraram nova escrita dramática. Outras cenas do texto-base foram completamente recortadas em função do jogo que a encenação demandava.

${ }^{4}$ A cena 12 preservou o mesmo nome da cena XX, a última na obra koltesiana, e seu conteúdo foi composto por boa parte da rubrica escrita pelo autor, colocada na montagem pelotense na voz de um personagemnarrador 
Exemplo disso é a cena 6, "Cabra-cega". O texto desta cena foi construído a partir de fragmentos das cenas II, V e VII de Koltès. A dramaturgista costurou frases koltesianas para compor uma situação de violência e assédio contra a figura feminina. Em cena, não mais um homem e uma mulher, como no original, mas três atores e uma atriz. Os homens ocupavam ali a figura de um coro masculino que se valia das ações e do texto para cercar e sufocar Léone, lançando-a de um ao outro como um brinquedo, como um objeto, coisificando-a e se divertindo com isso. A demanda da construção cênica orientou a composição dramatúrgica e foi trabalho da dramaturgista reposicionar os diálogos concebidos por Koltès, selecionando onde as violências verbais ocorriam e organizando-as de forma que tivessem o movimento crescente de tensão demandado pelo jogo.

A voz feminina ganhou lugar com as poesias de Angélica Freitas, que contribuíram fortemente ao olhar de antimisoginia que a encenação queria carregar. Também coube à dramaturgista articular fragmentos delas para compor com a cena criada, denominada "Mulheres nas janelas". Abaixo, alguns trechos que foram para o texto dramático final e demonstram a potência das palavras de Freitas:

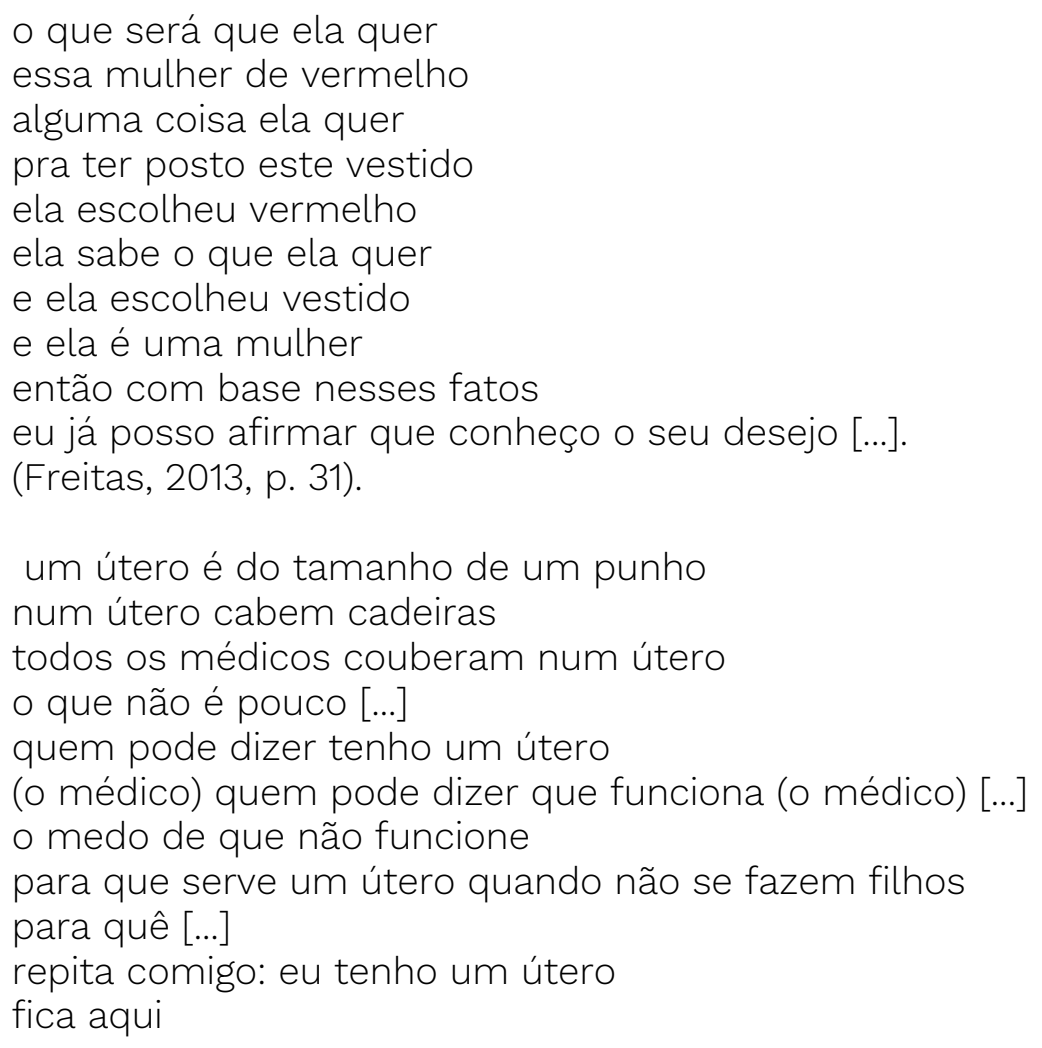


é do tamanho de um punho

nunca apanhou sol

um útero é do tamanho de um punho

não pode dar soco [...].

(Freitas, 2013, p. 59-61)

Nesta cena, duas atrizes penduravam parte de seus corpos em janelas do casarão, enquanto a atriz que interpretava a personagem Léone falava o texto com as poesias e realizava partitura física, tendo como elemento cênico principal o vestido vermelho junto ao corpo. A imagem dos corpos femininos pendurados, como carnes expostas, ou ainda como charque, cuja produção marca a História de Pelotas, remetia ao olhar para a mulher como um mero pedaço de carne e fortalecia a crítica à opressão contra as mulheres que a montagem abordava.

Além disso, a poesia de Freitas traz à tona a questão sobre concepções prévias em relação à mulher a partir do vestuário da mesma (no caso, o vestido vermelho), sobre suas intenções ao escolher esta peça considerada sensual, dialogando com as concepções que Horn e Cal têm sobre Léone, sejam elas de fragilidade, de interesse, de oportunismo ou de vulgaridade. Por que exatamente aquela mulher chega naquele local? Quais os interesses dela ali? Perguntas para as quais os personagens homens brancos têm respostas, mesmo desconhecendo os anseios dela, e agem conforme suas ideias, sem considerar as dela. A questão do útero, seu tamanho, força e suposta finalidade emerge em Freitas, levando a refletir sobre este órgão do corpo feminino e sobre como ele é percebido por mulheres e homens (simbolizado na poesia pelo médico), em especial no que diz respeito à propriedade do corpo feminino e discussões sobre a maternidade ao questionar sua função quando "não se fazem filhos".

A menção às charqueadas feita acima retornava à cena de maneira ainda mais direta no que se referia ao racismo. As fazendas de charque tinham como mão-de-obra os escravizados e as situações de trabalho eram desumanas. Pelotas era o local para onde muitos escravizados eram enviados para serem punidos, justamente por conta de tal insalubridade. A cidade foi construída pelas mãos de negros e negras. Informações históricas sobre o tema foram pesquisadas na obra de Gutierrez (2001) e compuseram o texto do póslogo, agregadas a dados e notícias 


\section{Urdimento}

recentes sobre violência contra mulheres e negros nos últimos anos, evidenciando que, no Brasil, a opressão segue assombrando estes dois grupos - alguns fragmentos do texto levado à montagem seguem abaixo junto com imagem da cena.

As unidades compostas de estância, charqueada e olaria tinham de 30 a 150 escravos. [...]

Navios negreiros: Amável Donzela, Caridade, Feliz Destino. Travessias realizadas: 34. Total de escravos transportados por eles: 11.240. [...]

56\% dos homens admitem que já cometeram alguma dessas formas de agressão: xingou, empurrou, agrediu com palavras, deu tapa, deu soco, impediu de sair de casa ou obrigou a fazer sexo. [...]

Adolescente é vítima de estupro coletivo no Rio de Janeiro: mais de 30 homens estupraram a jovem e postaram fotos e vídeos em redes sociais. $[\ldots]$

Cinco jovens negros têm carro fuzilado por mais de 100 tiros pela PM do Rio de Janeiro. Os rapazes tinham saído para comemorar o primeiro salário de Roberto de Souza, 16 anos. (Fernandes, 2016).

Figura 1 - Póslogo: "Pedaços de Corpos"

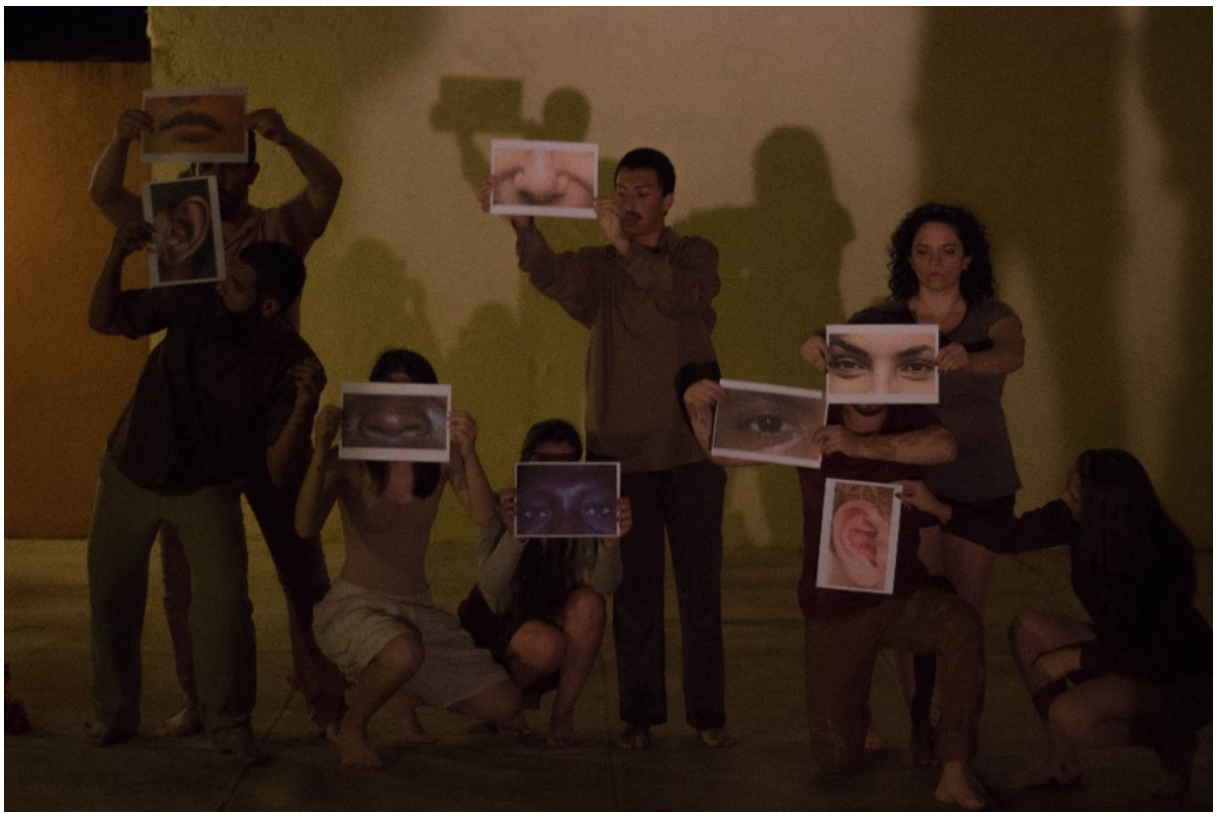

${ }^{5}$ Elenco: Mario Celso Pereira Junior, Lucas Galho, Gabrielle Winck, Juliana Caroline da Silva, Marco Antônio Duarte, Johann Ossanes, Maria Amélia Gimmler Netto e Fernanda Vieira Fernandes. Foto: Mike Dilelio. Casarão 8 - Museu do Doce, Pelotas/RS, outubro de 2016. 
Buscando sempre aproximação entre esses elementos externos, literários ou não, cada artista participante trazia estímulos que poderiam contribuir à criação. Foi assim que os filmes de Lars Von Trier serviram como estudo de situações de opressão na linguagem cinematográfica. Os pontos de umbanda e o canto de suas palavras entraram em cena carregando a ancestralidade e religiosidade do povo negro, e é simbólico que fossem entoados justamente dentro do casarão colonial escravagista. Os pontos foram pesquisados por alguns colaboradores que frequentavam terreiros de umbanda na cidade de Pelotas e tinham envolvimento direto com a religião.

Figura 2 - Cena 4: "A Nuvem"

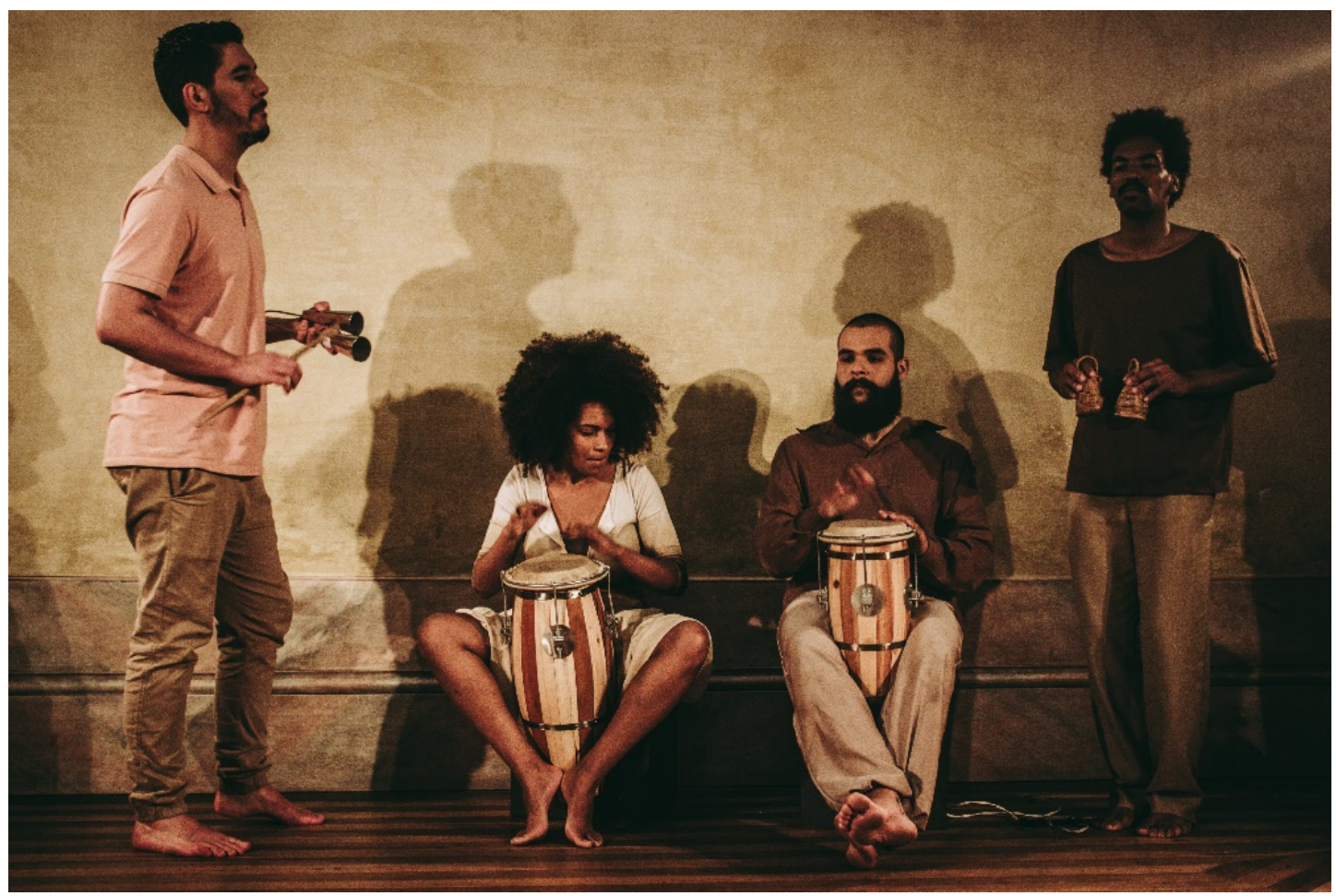

E, por fim, as palavras dos próprios artistas criadores entraram na versão final do texto. A escrita individual surgiu através de perguntas norteadoras (sendo a primeira delas: "O que te traz conforto e o que te desconforta?"). A cena 5, "O que

${ }^{6}$ Elenco: Ana Paula Melo, Lucas Galho, Mario Celso Pereira Junior e Airton Marino. Foto: Mike Dilelio. Casarão 8 - Museu do Doce, Pelotas/RS, outubro de 2017. 
há disso em nós" apresentava, por exemplo, os seguintes trechos de testemunhos de uma atriz e de um ator, respectivamente:

Ela foi para uma festa com os amigos, dançou, bebeu um pouco e beijou um amigo. Ele a levou para um quarto da casa em que estavam e a beijou. Olhou muito para ela e a beijou mais forte. Apertou seu braço e tirou a própria calça. Ela disse que não queria, mas ele queria, então a apertou mais contra si e a beijou mais forte. Ela gritou, esperneou, o empurrou, correu e foi embora chorando. Os pais dela disseram que ela pediu, pois estava na festa, pois estava bêbada, pois o estava beijando.

Eu sempre fui negro, mas eu descobri que era da pior forma. Voltando para casa, depois da escola, fui enquadrado pelos porcos. Eles remexeram minha mochila, tiraram meu capuz com força e me fizeram milhares de perguntas como: o que estava fazendo ali e por onde iria. Respondi que estava indo para casa só... de recompensa fui chamado de macaco e um tapa "para ficar esperto". Naquele dia me olhei no espelho durante muito tempo. Um branco nunca seria chamado de macaco... foi aí que percebi que moreninho não consta no vocabulário deles.

Todos esses elementos foram estimulando a criação do coletivo e, além disso, permitiam que os participantes mergulhassem na temática da encenação e, também, se colocassem, por vezes, no lugar uns dos outros. O emaranhado de materiais transcriados e organizados pela dramaturgista gerou um texto pulsante, que se valeu da própria teatralidade oriunda dos ensaios, uma característica da escrita dramática da atualidade. Silvia Fernandes comenta sobre a contaminação do drama pela cena contemporânea, especialmente no que diz respeito a não ser mais objetivo do texto construir uma ação dramática que deva ser atualizada no palco. O texto apropria-se da teatralidade da cena:

O resultado da apropriação da teatralidade pela dramaturgia mais recente é que o texto literário ganhou novo estatuto. O dramático ainda se conserva no modo de enunciação, na construção dos diálogos, monólogos ou narrativas e, algumas vezes, no desdobramento das personagens. Mas a qualidade teatral deixa de ser medida pela capacidade de criar ação. Agora teatral pode ser apenas espacial, visual, expressivo no sentido da projeção de uma cena espetacular. (Fernandes, 2010, p. 163)

No processo de criação de Combate isso se deu a cada encontro/ensaio, 
justamente quando palavras, signos, sensações e imagens se colocavam como material para a escrita dramática. Ao final do processo, o grupo tinha um texto, uma obra escrita, que dialogava, claro, com a encenação e sua teatralidade.

\section{Encenação e direção rotativa de cenas: visão da parte, visão do todo}

A experiência na qual se desenvolveu a montagem Combate: corpos mortos, vivos e por virvinculava-se também ao projeto de pesquisa "Composição de cenas e condução de grupo em processo colaborativo de criação teatral no Laboratório de Dramaturgismo e Direção rotativa de cenas", coordenado por Maria Amélia Gimmler Netto. A pesquisa visava investigar possibilidades de se compor cenas em grupo, tendo a direção de cenas como função central a ser experimentada, de maneira rotativa, por todos integrantes do laboratório. O estudo das diferentes funções teatrais dentro da criação colaborativa foi aliado à prática da encenação e buscou identificar quais aspectos da direção teatral ativam e aprimoram o trabalho do profissional que se propõe a ensinar teatro por meio de processos criativos colaborativos.

As diversas ideias que estão por trás da criação de uma obra pedem uma solução formal diferente em cada caso. O estilo de uma obra teatral depende das ideias articuladas em sua criação. Assim como as ideias, o estilo se define e redefine em função da forma possível de se colocar uma ideia em ação, do modo de colocá-la em cena. A proposta da direção rotativa de cenas parte do princípio de experimentar diferentes ideias, inicialmente individuais, em ação coletiva. Tendo um texto dramático como primeiro estímulo, por exemplo, cada membro do elenco é convidado a escolher um trecho do texto que the foi significativo e elaborar uma ideia de cena para este. Quando um membro da equipe apresenta ao grupo a sua ideia, ele a põe em cena contando com a participação de toda a equipe. Ou seja, ele dirige a sua cena, selecionando atores e atrizes, materiais, espaço, texto, ações, jogos, imagens, áudios, tudo aquilo que contemple a sua ideia. O integrante conduz o elenco para que, improvisadamente, se chegue a um material cênico em estado bruto. Em outras palavras, nesse processo, todos os 
participantes se arriscam na tarefa de improvisar o encenar e treinar o olhar ao todo e às partes deste todo, simultaneamente testando ser, ora quem conduz, ora quem é conduzido. Essas cenas dirigidas improvisadamente passam a compor um repertório coletivo de cenas, que será base fundamental para o trabalho de encenação e dramaturgia, feito em uma etapa posterior.

Dois artistas cujas práticas convidam e autorizam a refletir sobre como são acordadas as hierarquias das funções criativas nos processos artísticos colaborativos de criação são o brasileiro Antônio Araújo, diretor do grupo Teatro da Vertigem, e a francesa Ariane Mnouchkine, diretora da companhia Théâtre du Soleil. Seus modos de conduzir composições cênicas coletivas são singulares e esta marca se faz presente nas suas encenações. Evidentemente, cada processo criativo é único, porém há princípios que se repetem e merecem destaque, ao observar-se o modo de compor de cada artista ou de cada coletivo de artistas.

Por exemplo, em Araújo, a escolha prévia do espaço físico em que a montagem se dará, o fato dele dirigir observando improvisações individuais e coletivas de atores e atrizes, bem como a presença constante do dramaturgista na sala de ensaio, podem ser considerados princípios fundamentais de seu trabalho. Nas palavras do encenador:

Se dramaturgo e diretor necessitam sempre transitar do fragmento ao todo e do todo ao fragmento, por que seria diferente com os atores? Esse modelo de um ator que mergulha cegamente em uma personagem, se alheando ou pouco se interessando pelo discurso geral da peça, nos parecia obsoleto e limitador. O mesmo podendo ser dito em relação aos outros colaboradores artísticos, ou seja cenógrafo, iluminador, figurinista e diretor musical. Todos eles apesar de comprometidos com determinado aspecto da criação, precisam integrar-se numa discussão de caráter mais generalizante. (Araújo, 2018, p.15).

Na visão do diretor, um ator não cria somente o personagem, um iluminador não cria apenas a luz do espetáculo, o sonoplasta não propõe unicamente a trilha sonora. Todos os integrantes da equipe criam em conjunto a obra que será apresentada ao público.

Já no caso de Mnouchkine, os longos períodos de improvisação para que os 
integrantes do elenco criem movimentos e ações, o uso de elementos materiais como objetos cênicos e figurinos nas improvisações, bem como a criação cênica aliada às experimentações sonoras do diretor musical do grupo são princípios observados como fundamentais em seu trabalho de direção:

\begin{abstract}
A improvisação, para A. Mnouchkine, é o fundamento do teatro. A criação coletiva, nutrida pela improvisação, é o modo de trabalho único e específico do Soleil, é nisso que ele se distingue. Mesmo se, nessa nova etapa, o papel da diretora-chefe da troupe parece acrescido, pois ela representa mais ainda o centro, a coluna vertebral de um grupo renovado. Mas é a composição do grupo que mudou, não seu desejo de um teatro que se escreverá coletiva e diretamente sobre um palco. (Picon-Vallin, 2017, p.125).
\end{abstract}

A afirmação é da pesquisadora Béatrice Picon-Vallin referindo-se à chegada de uma nova geração de atores à trupe no final da década de 1970 e início da década seguinte. Chegada esta que gerou uma coabitação entre atores mais velhos e mais novos no grupo, que, na época em que se refere a autora, montava clássicos como Ricardo // e a Era de Ouro. "É sempre difícil descrever o trabalho do Soleil, multidirecional, feito de tantas tentativas, pesquisas, encontros, acasos e intuições, no qual a pesquisa é também formação" (Picon-Vallin, 2017, p.129), ela adverte, chamando atenção à dimensão investigativa e formativa presente sempre no modo de criação da companhia.

Conforme mencionado acima, o processo colaborativo de criação problematizado neste artigo teve como ponto de partida a leitura do texto koltesiano. Através deste mesmo estímulo textual cada membro da equipe escolheu um trecho que the impactou e concebeu sua ideia de cena. Posteriormente, cada artista apresentou a ideia ao grupo e a conduziu para materializá-la no instante do aqui e agora da sala de ensaio. Evidentemente que nesta experiência está implicada a improvisação de ações realizadas pelos atores e atrizes, e as sugestões trazidas por cada sujeito de acordo com sua bagagem cênica e suas habilidades. Porém, o princípio fundamental da proposta mantém o seu foco no modo de encenar.

Em seu momento inicial, o laboratório contou com uma equipe de nove 
artistas. Logo, foram criadas nove cenas a partir dessa leitura e, posteriormente, outras nove a partir de outro estímulo: a escrita de testemunhos. Foram reservados momentos em sala de ensaio para a leitura e discussão do texto dramático e para a leitura dos testemunhos. O trabalho criativo englobava duas esferas: a visão de cena e a visão de mundo de todos os integrantes. Transitou-se assim do fragmento ao todo e do todo ao fragmento, conforme as palavras de Mnouchkine publicadas por Picon-Vallin, e produziu-se o material que viria a compor o discurso cênico geral da peça, a partir de lógicas individuais compondo em coletivo. Serão apresentados a seguir dois exemplos de cenas surgidas em estado bruto, no improviso dos ensaios iniciais, através do exercício da direção rotativa e seus desdobramentos em cenas que passaram a compor a versão final da obra - cenas estas que já foram mencionadas na seção anterior, desde o ponto de vista da criação dramatúrgica.

Partindo de um diálogo presente na cena IX de Combate de negro e de cães, no qual dois personagens tentam se comunicar falando cada um em uma língua diferente: Léone em alemão, e Alboury em wolof? em que os atores e as atrizes ficavam fazendo cócegas uns nos outros, como se fosse um diálogo de cócegas. A esta cena foi dado o nome de "Cócegas". Já com base em outro trecho do texto, no qual dois personagens masculinos, Horn e Carl, falam de sua visão acerca de Léone, outro integrante dirigiu uma ação em que uma mulher tentava movimentar-se e deslocar-se, encontrando barreiras físicas formadas pelos corpos de três homens. Essa cena intitulou-se "Desconforto". Ainda outra cena criada e dirigida por uma terceira integrante foi um jogo de cabracega: a atriz estaria vendada e os três atores participantes estariam jogando com ela. A cena, no improviso da direção, evoluiu para outro jogo, o "bobinho", e, assim, foi ganhando densidade e tensão, acrescida de falas assediadoras dos

\footnotetext{
${ }^{7}$ Conforme a tradução brasileira de Combate de negro e de cães, referência indicada ao final do artigo e usada no processo de criação do laboratório, wolof ou uolof é uma língua falada no Senegal, Gambia, sul da Mauritânia, estendendo-se ainda através de línguas aparentadas até o Burkina Faso. Cumpre ressaltar que, tanto no texto original de Bernard-Marie Koltès, quanto na referida tradução para a língua portuguesa, não consta a tradução das frases em wolof, por ser a comunicação para além da língua falada uma discussão presente na obra koltesiana. Porém, durante o processo criativo da montagem, os artistas da equipe sentiram a necessidade de conhecer o sentido das frases e essa tradução foi gentilmente realizada pelo professor senegalês, radicado no Brasil, Mamadou Alpha Diallo.
} 
personagens masculinos e latidos de cachorro.

Figura 3 - Cena 6: "Cabra-cega”. Elenco: Juliana Caroline da Silva, Lucas Galho, Johann Ossanes e Mario Celso Pereira Junior. Foto: Mike Dilelio.

Fábrica Cultural, Pelotas/RS, junho de 2016

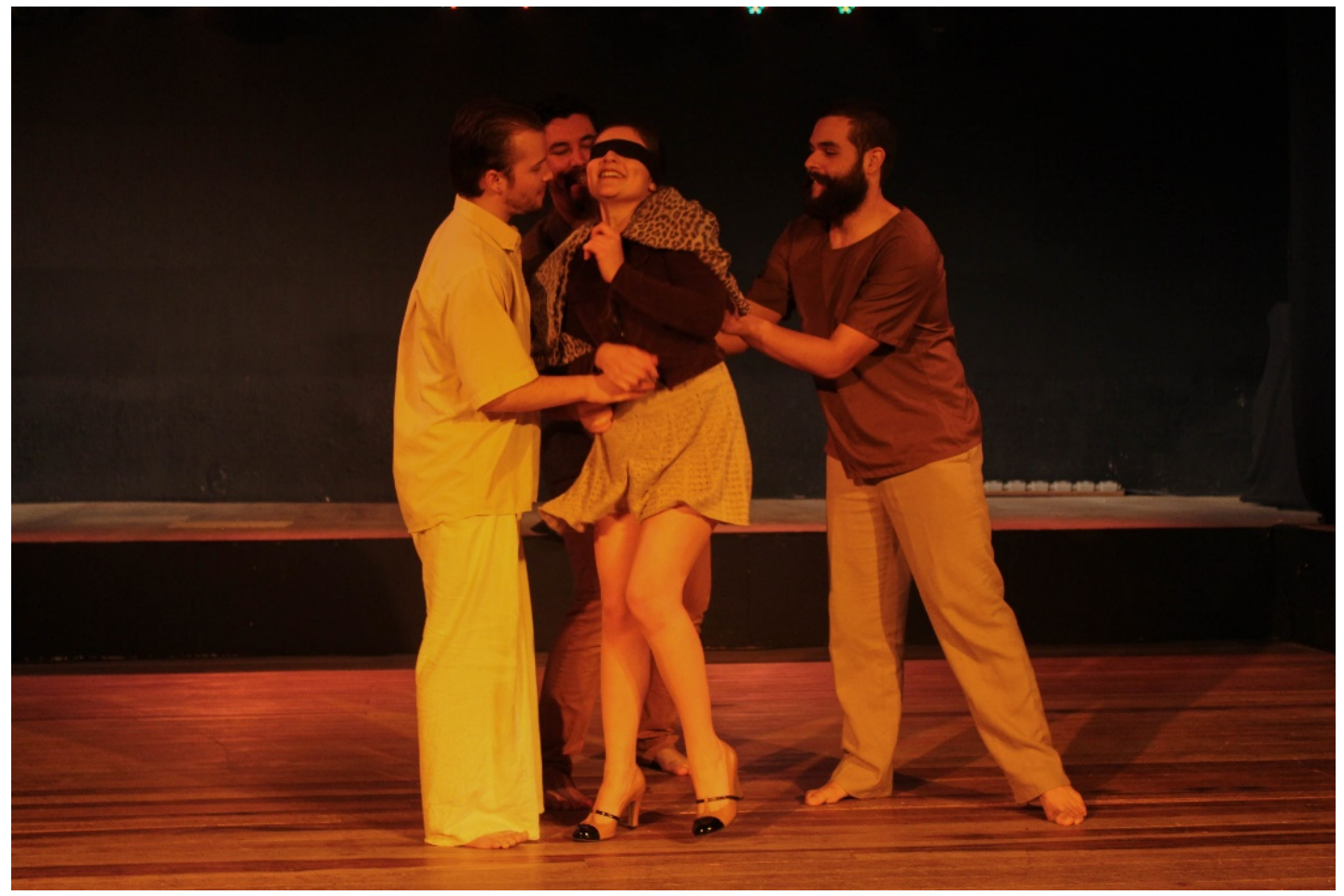

Ações dessas três cenas matrizes fundiram-se posteriormente para compor a cena 6, "Cabra-cega", do roteiro final. Na imagem acima é possível observar o jogo de cena entre a atriz com os olhos vendados e os três atores que a assediam.

Já aquela que veio a ser a cena 11, "Mulheres nas janelas" surgiu a partir de uma foto que compunha o testemunho de uma atriz e que foi posta em cena por outra artista no espaço do casarão, enquanto uma segunda atriz lia um trecho do referido testemunho. Forma semelhante foi mantida na versão final, mas desta vez tendo como texto da cena os fragmentos de poemas de Angélica Freitas. A foto abaixo mostra a versão final da cena que teve ênfase na fragmentação entre o seu caráter visual e textual. Ela foi composta pela imagem estática das mulheres penduradas e desnudas nas janelas, sobreposta pela imagem da atriz, com o vestido vermelho, em frente ao foco de luz de chão, que projetava sua sombra em 
movimento e tamanho grande na mesma parede onde estavam os corpos.

Figura 4 - Cena 11: "Mulheres nas janelas". Elenco: Juliana Caroline da Silva, Gabrielle Winck e Fernanda Vieira Fernandes. Foto: Mike Dilelio.

Casarão 8 - Museu do Doce, Pelotas/RS, outubro de 2016

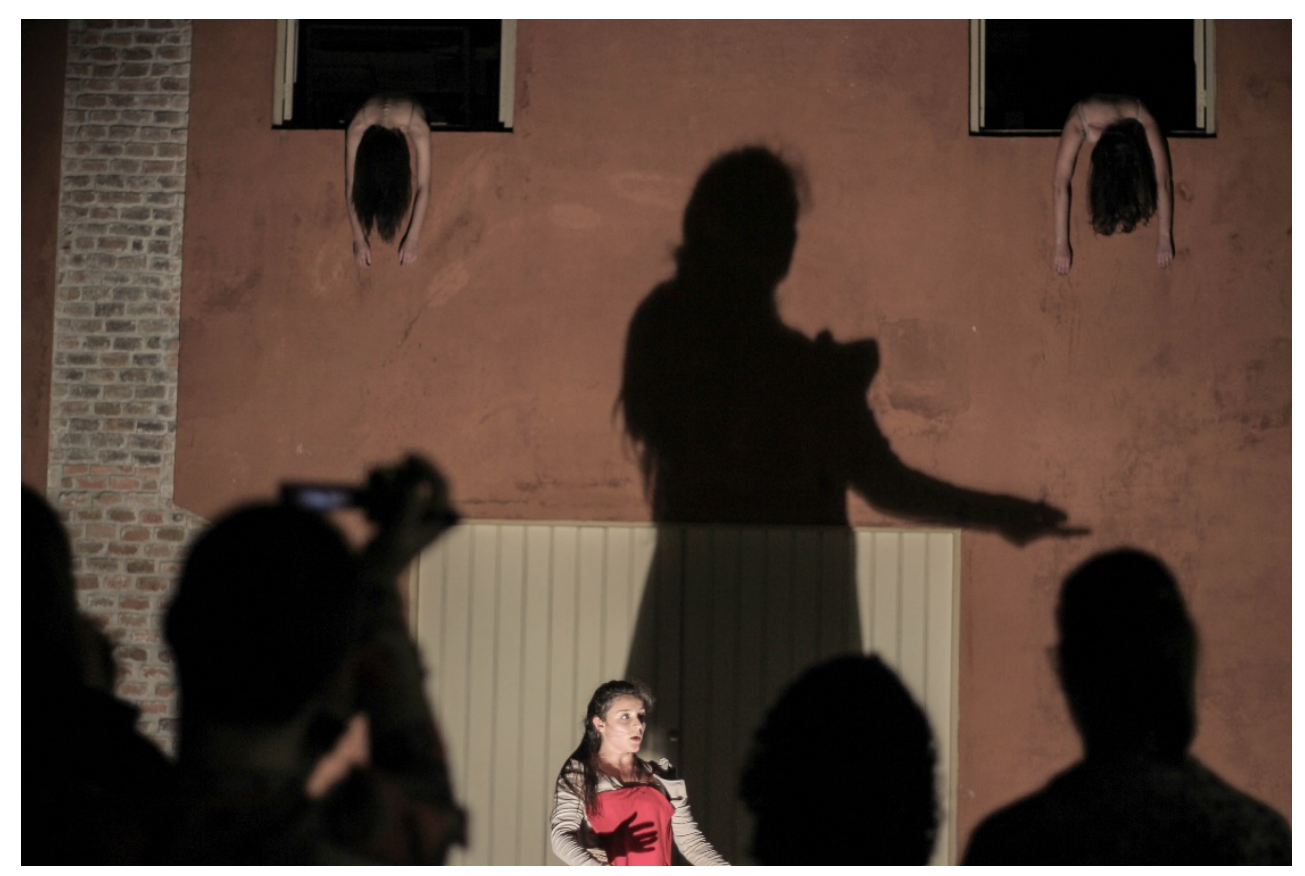

Além do aspecto poético, o trabalho de encenação teve também uma dimensão formativa, na medida em que provocou a realização de aprendizagens coordenadas e simultâneas à criação de cenas propriamente ditas. Muitos membros da equipe precisaram aprender novas habilidades por exigência das cenas. Aprender a pronunciar frases em outra língua, como o wolof, entrevistar falantes de línguas estrangeiras, como alemão e francês, gravar e editar áudios, manejar diferentes refletores e lâmpadas, operar áudio, vídeo e luz em cena, pois as operações eram feitas pelo próprio elenco. Habilidades musicais foram imprescindíveis para cantar em cena e tocar percussão em conjunto. O treinamento musical contou com o suporte de profissionais da música que prepararam o elenco para tanto. A cena 4, "A nuvem”, exigia, por exemplo, que uma das atrizes coordenasse a sua fala com as batidas do tambor e os movimentos que o coro executava, aliando o ritmo da música, da partitura física e 
do texto. Buscou-se, assim, estabelecer um repertório de habilidades comum, a partir de um trabalho multidirecional, que foi físico, intelectual, emotivo e poético.

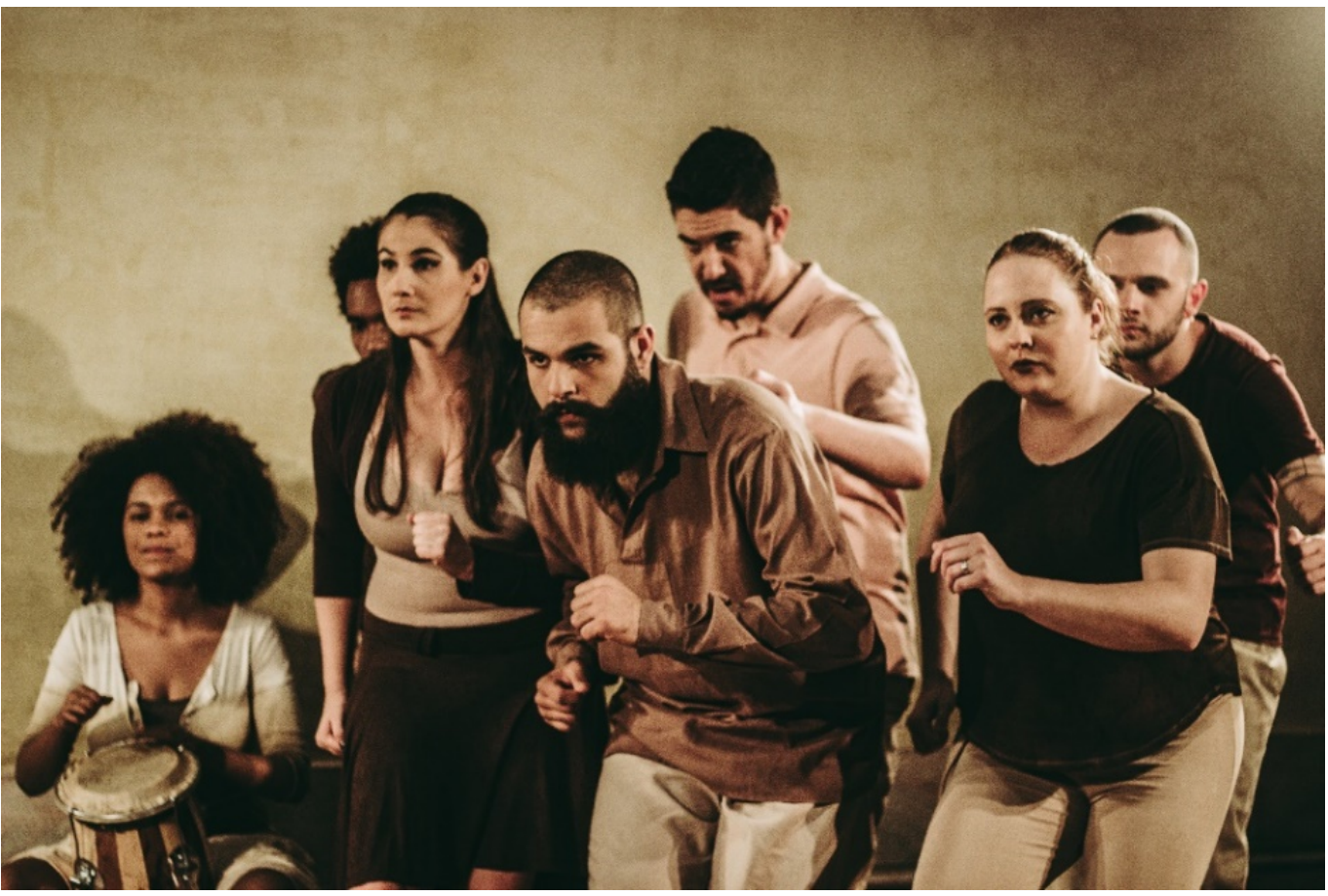

Em relação ao preparo de elenco, a ênfase da direção se deu em atividades que desenvolvessem, em via de mão dupla, o trânsito do individual para o coletivo e do todo para a parte. A prática de yoga e meditação foi utilizada como tentativa de conexão dos atores e atrizes consigo mesmos, com seus corpos, limites físicos, pensamentos e capacidade de concentração. Tal contato consigo antecede a conexão, ou tentativa de conexão, com os outros que compõem a mesma equipe. O estímulo à criação dos testemunhos e a posterior leitura em voz alta desses textos íntimos, e a sua redistribuição para que a ideia de cena, a partir do testemunho, fosse de outra pessoa que não o autor ou autora, foram também estratégias de criar um fluxo comum entre as visões individuais e coletivas dentro

${ }^{8}$ Elenco: Ana Paula Melo, Airton Marino, Fernanda Vieira Fernandes, Mario Celso Pereira Junior, Lucas Galho, Cibele Fernandes e Thairone Dorneles. 
do grupo, criando intimidade, estranhamento e confiança.

A lógica de criação apresentada acima implicou diretamente na poética da obra. Seja na sua dramaturgia, seja na sua encenação, bem como nas opções cenográficas e no trabalho do elenco na atuação e no manejo da técnica em cena. A primeira etapa do processo criativo foi sucedida por outra em que a encenadora e a dramaturgista compilaram, dentre as cenas criadas e considerando as mais significativas já pré-selecionadas por toda a equipe, um primeiro roteiro de cenas e uma primeira versão do texto. Posteriormente, esse material voltou para a sala de ensaio, foi discutido, questionado e experimentado por meio de trabalho colaborativo, com seus acordos, alguns consensos e dissensos, e muito conflito.

\section{A participação e a dimensão coletiva do público nas artes cênicas}

Criar estratégias de participação e de relação com o público nas artes cênicas provoca o surgimento de novas estratégias de relação entre atores/atrizes e personagens, ficção e realidade. O pesquisador espanhol Óscar Cornago observa que uma forma cênica que se dirige ao público, de maneira em que se borram os limites entre personagem e atores/atrizes, corresponde a um contexto complexo que pode acabar por conduzir a uma ação coletiva em que a audiência faz parte:

Esa primer persona deja ver el vosotros al que se dirige, encarnado por el propio público y al que se interpela directamente como un modo de interrogarse por el sentido de ese encuentro. ¿Qué significa salir a escena, qué estamos haciendo aquí? Según los modos de situarse en este espacio de comunicación, la construcción del otro frente al que se realiza la acción va a ser distinta. (Cornago, 2016, p. 149).

Segundo ele, a ação de questionar o sentido desse encontro e o replanejar a criação através desta relação com o outro está na base de produção de muitos artistas cênicos que alcançaram reconhecimento internacional a partir dos anos 2000. Nesse contexto, a teatralidade já não se projeta a partir de um cenário existente sobre um público disperso em um espaço, mas sim, ela gira sobre si mesma, sobre seu ponto de partida que é o olhar do espectador, tratando de 
limitar-se sobre este lado que é mais improvável e menos definido, todavia é, também, mais determinante pelo olhar e a presença, do outro, do que vem de fora, do estranho.

Se hace coincidir el escenario con la platea y el espacio de actuación con el lugar de esa mirada. La teatralidad no tiene ya ningún otro objeto de representación que el propio público tratando de ser distinto de sí mismo. El mecanismo de distancias y tensiones entre actor y personaje característico de la teatralidad opera sobre ese público al que se invita a dejar de ser público sin dejar de serlo nunca al de todo. El hecho mismo de mirar se convierte en una forma más de actuar. Se deja sentir la potencia social que reside incluso o sobre todo en acciones mínimas, como mirar, estar, dudar, no atreverse, emocionarse o ponerse en relación. Sin dejar de ser público, el público es también algo más. A ese algo más como materia prima de la construcción social se dirigen estas obras. (Cornago, 2016, p. 150).

Para o pesquisador espanhol, este lugar indefinido entre plateia e espaço da ação, entre personagens e atores/atrizes, se propõe como condição de uma ação coletiva em que todos são espectadores e atores ao mesmo tempo. É a qualidade pública que todos têm em comum. Não existe o que olhar se não a si mesmos em um processo de se estar construindo como sujeito social e autônomo. A atuação deixa de estar localizada em um ator ou em um grupo de atores circunscritos em um cenário para ser uma realidade compartilhada, um lugar de mobilidade que é frágil e indeterminado, que aparece e desaparece na medida em que a obra o ativa.

A completude da encenação e da dramaturgia de combate se deu na presença do público, que percorria com o elenco os espaços do casarão, como se fosse construindo uma parte do enredo a cada novo ambiente. O primeiro dispositivo de participação usado na encenação estava na perspectiva poética, no fato de que membros do elenco atuavam em cinco dimensões de presença cênica: ora como atores que representavam personagens, ora como atores que integravam o coro, ora como narradores, ora como técnicos de som e de luz ou, ainda, como espectadores. Uma particularidade da obra foi que a dramaturgista e a encenadora também participaram do elenco. 
Figura 6 - Cena 12: "Últimas visões de um cercado longínquo". Ator-narrador: Marco Antônio Duarte e público

Foto: Mike Dilelio. Casarão 8 - Museu do Doce, Pelotas/RS, outubro de 2016

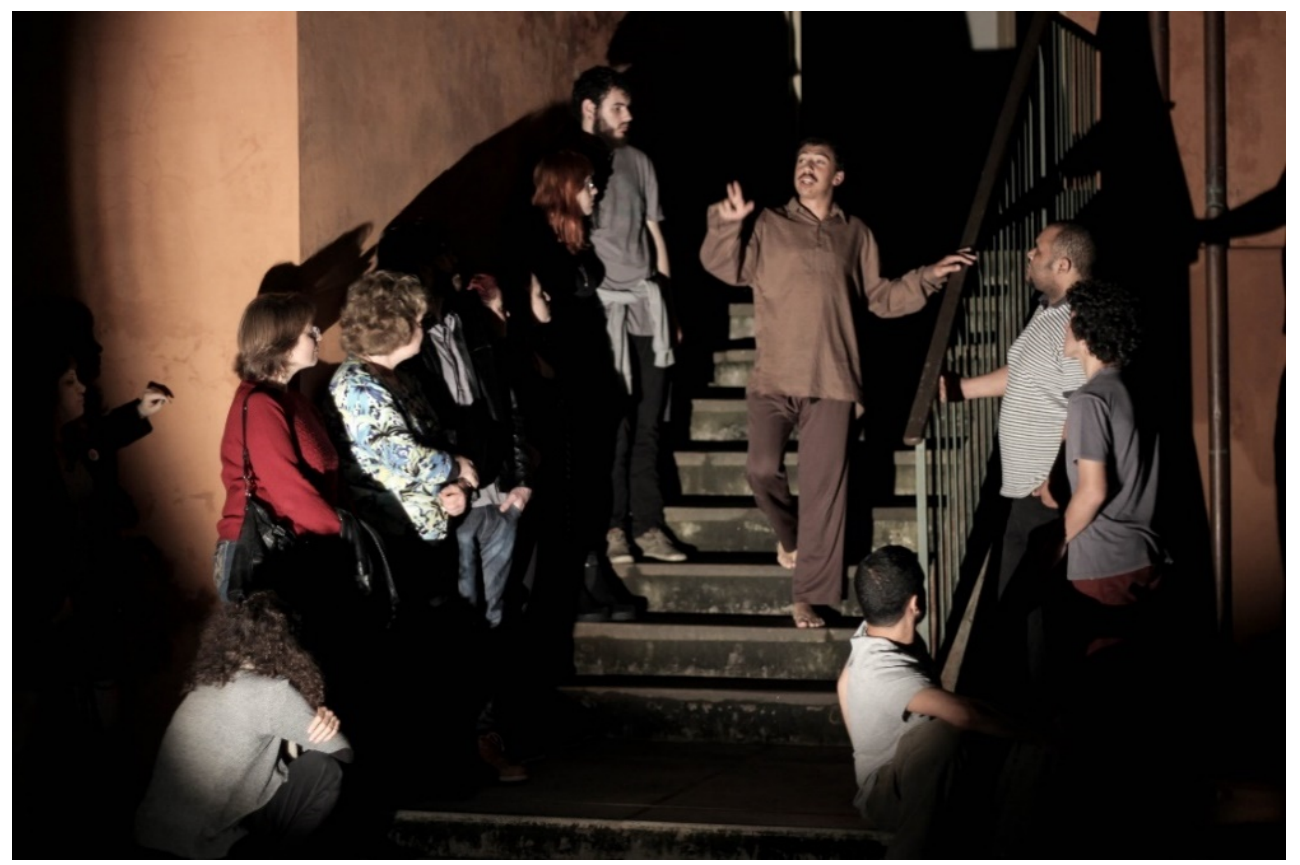

Outro dispositivo de participação, em uma perspectiva estética, foi a relação entre espectadores e elenco. Em alguns momentos, ambos se fundiam em uma mesma ação de observação do entorno, da cena, do outro e de si. Em outros, a fusão se dava nos deslocamentos pelos circuitos internos do casarão, delimitado pela sua configuração espacial, desde o adentrar o espaço da senzala/porão habitável, o passar pelo pátio, subir as escadarias, percorrer o corredores estreitos e passar aos aposentos, o que gerava oportunidades de interação dos espectadores entre si e deles com os artistas. Em outros momentos, uma parte do público assistia à outra parte do público em primeiro e/ou em segundo plano na cena.

Na Cena 3, "É preciso ser cooperativo", os espectadores eram tratados por uma das personagens como clientes de uma transação imobiliária. A atriz, ao passo que conduzia os espectadores por alguns aposentos do casarão, os colocava em um corredor e mostrava a eles detalhes de suas aberturas de portas 
e janelas, vidros, balcões e espaços externos, como jardins e a rua. Enquanto isso, a atriz, representando uma corretora de imóveis, falava um texto de Horn, extraído e adaptado da cena IV de Combate de negro e de cães. Nele, o chefe do canteiro de obras explica a Alboury um projeto utópico que ele mesmo elaborou para abrigar toda a população mundial em edifícios arranha-céus localizados na França e valendo-se do restante do mundo, em especial os continentes africano, americano e asiático (começando pelo primeiro), como a reserva de extração de riquezas. A ideia, evidentemente, demonstra uma visão eurocêntrica, individualista, colonizadora, pouco empática e que não leva em consideração o Outro, suas peculiaridades, sua cultura e seus valores, que torna homogêneos os sujeitos sob a pretensão de cooperação entre eles.

\section{Figura 7 - Cena 3: "É preciso ser cooperativo". Atriz: Gabrielle Winck e público. Foto: Mike Dilelio. \\ Casarão 8 - Museu do Doce, Pelotas/RS, outubro de 2016}

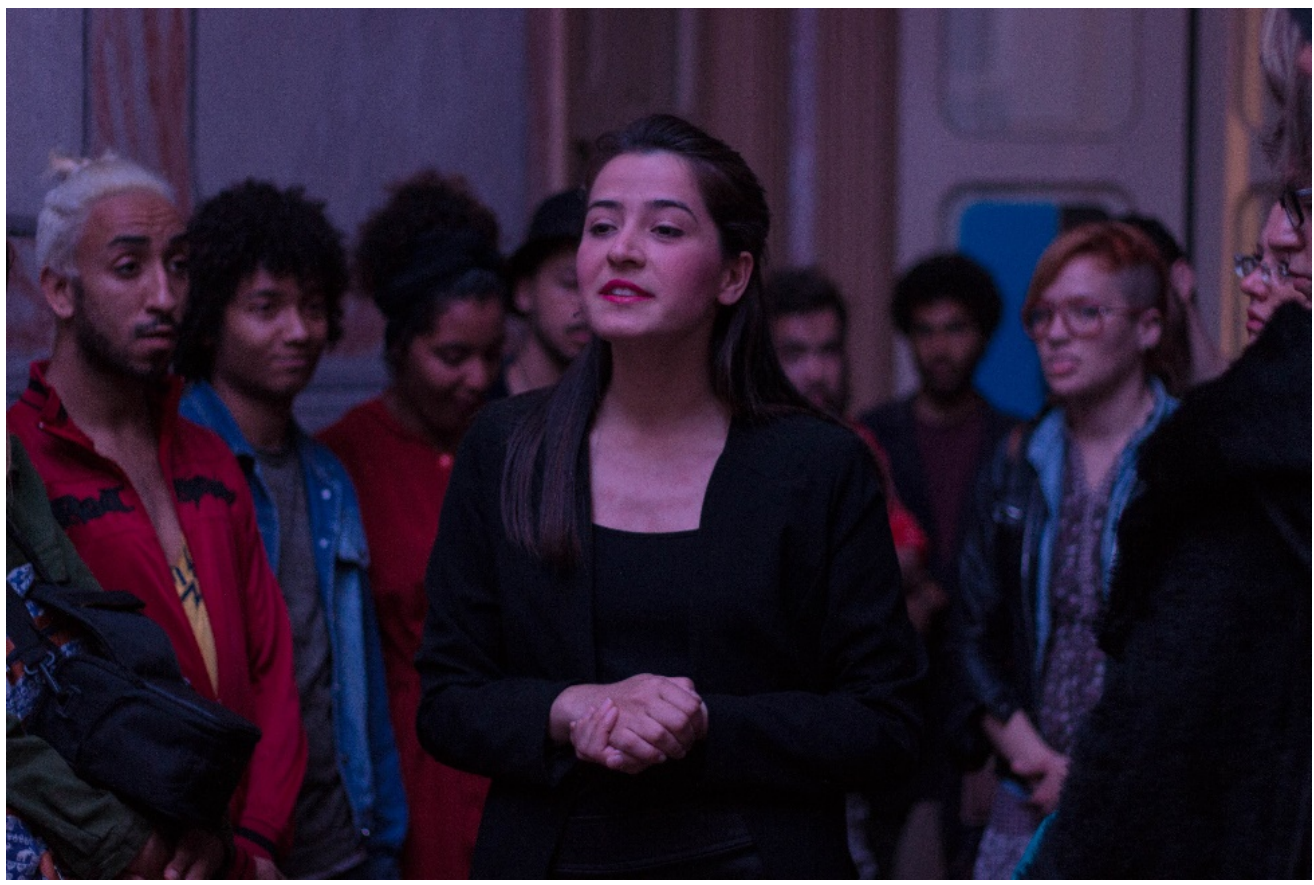

Durante o Prólogo, "A morte de Nouofia”, o público era conduzido a entrar no espaço arquitetônico do porão habitável do velho casarão colonial pelotense e a cena que transcorria ali convidava-o a sentir-se como uma pessoa escravizada, encerrada em uma senzala, que assiste ao momento da morte de um dos seus 
por exaustão. O público deixava de ser apenas público, no sentido de ser quem está ali para ver, e passava a ser algo mais. O ato de assistir permanecia acontecendo, porém a ele se acrescentava uma ação que era realizada pelo público também em cena.

Figura 8 - Prólogo: "A morte de Nouofia”. Ator: Airton Marino

Foto: Mike Dilelio. Casarão 8 - Museu do Doce, Pelotas/RS, outubro de 2017

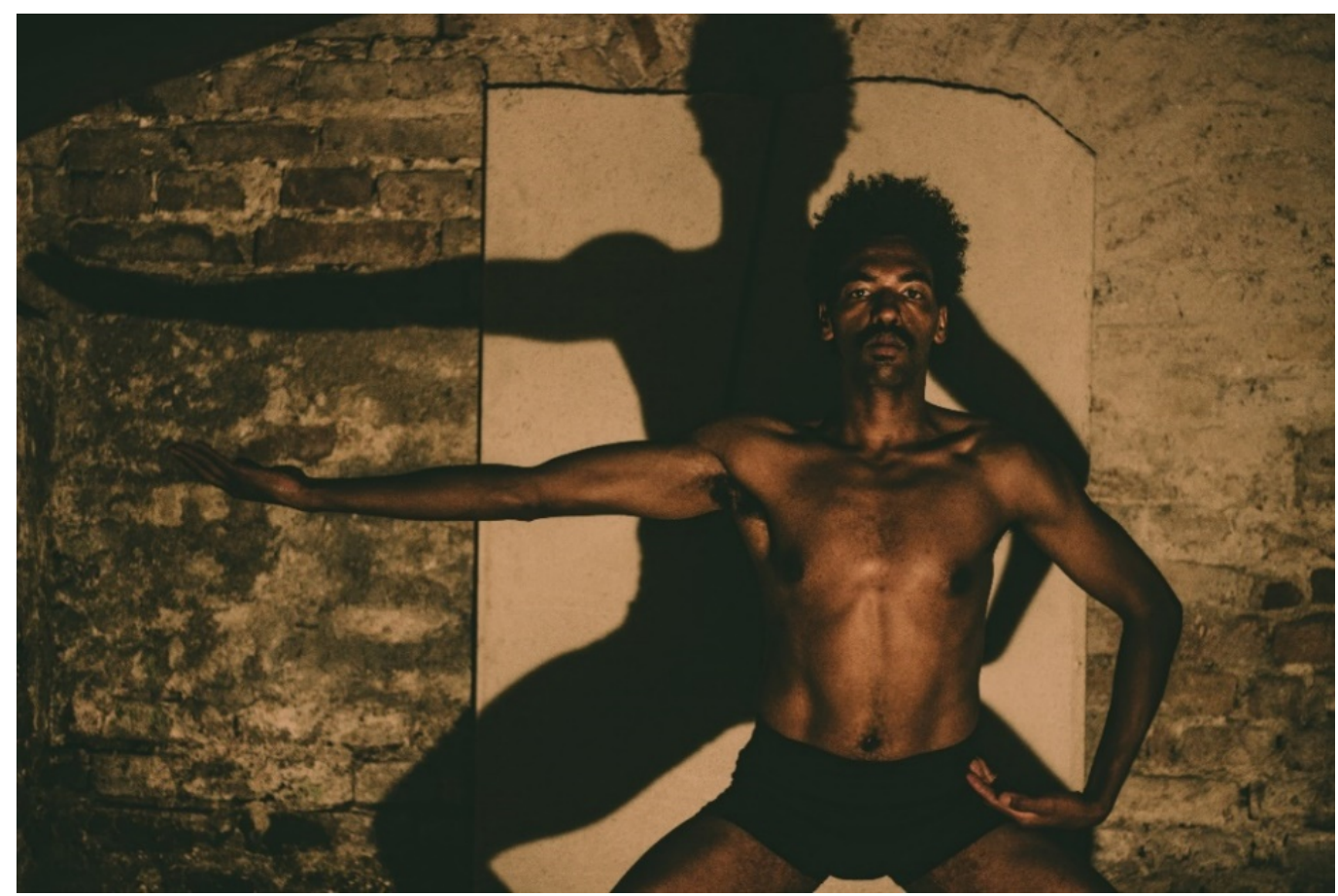

Houve ainda outra instância de participação, na qual o público compunha com algumas das atrizes um grande coro. Isso acontecia em dois momentos da encenação: o primeiro, no final do prólogo supracitado, quando o coro de mulheres conduzia o público de dentro da senzala para o pátio interno do casarão para dar início à cena 1, "Antígona - A busca pelo corpo". Na transição, o texto falado pelas atrizes, enquanto mesclavam-se ao público e o conduziam, era:

As mulheres cobrem escondidas os corpos dos operários mortos, galhos e palmas, para protegê-los do sol e dos urubus. Durante o dia, na atividade do canteiro, os caminhões passam por cima, e já de noite, as mulheres voltam a pousar novos galhos. No final de alguns dias e algumas noites, se formam pequenos montes de galhos e de carne misturados, 
que se fundem progressivamente na terra. [...] A mãe de Nouofia, quando a preveniram da morte do seu filho, no canteiro dos brancos, decidiu apesar dos avisos que the davam, se arriscar até lá, a fim de pousar galhos sobre o corpo para protegê-lo dos pássaros. No entanto, por precaução, ela cobriu o seu rosto com tinta branca para que a morte, que rondava por lá, não a reconhecesse pelo que ela era. (Koltès, 2010, p. 122-123).9

Já no segundo momento, o coro fazia um presságio da fuga da personagem Léone, que se destacava do coro de mulheres e avançava rumo à saída da casa. O coro narrava uma rubrica poética concebida a partir de didascálias das cenas VI e IX do texto de Koltès e compunha a Cena 10, "Chuva pelo avesso", do roteiro final. Naquele momento, quatro atrizes conduziam o público da antiga sala de jantar do casarão até a sala que dá acesso ao pátio interno, para onde o público se deslocava, pela última vez, para acompanhar as cenas finais.

\section{Para algumas situações parece não restar caminhos, apenas o combate}

Diante de um panorama nacional que mostra uma sociedade imersa em conflitos políticos e ideológicos, constata-se, infelizmente, a crescente desvalorização das ações educativas em todos os âmbitos, desde a educação básica ao ensino superior. Ao mesmo tempo, a produção artística nacional sofre também fortes represálias das instituições governamentais e por parte da sociedade civil. Neste contexto, são muitas as ações artísticas que vêm emergindo como forma de resistência, encontrando espaços, pessoas, forças e afetos para reagir, responder, questionar e combater padrões sociais opressores vigentes.

Neste artigo, refletiu-se sobre uma dessas propostas. Dentro da academia, fora do âmbito da arte profissional e centrado no trabalho com jovens e adultos em formação ou início de carreira, o laboratório abordou em um processo de

${ }^{9}$ Os textos desse coro foram extraídos das Notas que acompanham o texto dramático Combate de negro e de cães, mais especificamente das notas "Sepulturas de operários" e "Mãe de Nouofia". Esses escritos do autor foram elaborados durante sua estadia no canteiro de obras da Nigéria e serviram, posteriormente, como base para a escrita do texto, caracterizando-se como uma espécie de diários particulares dos personagens. 
criação de cenas e escrita dramática questões problemáticas da sociedade brasileira contemporânea, no caso o machismo e o racismo. O processo colaborativo da criação e o caráter de participação em todas as instâncias, desde a gênese das cenas, passando pela composição do texto e, por fim, imbricando artistas criadores e público, fez de Combate: corpos mortos, vivos e por vir uma potente experiência artística e pedagógica. Fomentou-se a autonomia e a colaboração em tempos de reconhecimento da onda opressiva que vive o Brasil e de sua crônica e aguda crise democrática. Diante de situações não mais admitidas, não cabem outras saídas: cabe apenas encontrar formas de combatê-las.

\section{Referências}

ARAÚJO, Antônio et al. FERNANDES, Silvia [org.]. Teatro da Vertigem. Rio de Janeiro: Cobogó, 2018.

CAMPOS, Haroldo de. Transcriação/ org. Marcelo Tápia, Thelma Médici Nóbrega. São Paulo: Perspectiva, 2015.

CORNAGO, Óscar. Estrategias de participación y relación con el publico en las artes escénicas en España a comienzos del siglo XXI. Revista Cena, n. 20, Porto Alegre, p. 145-158, 2016.

FERNANDES, Fernanda Vieira. Combate: corpos mortos, vivos e por vir (texto dramático). Laboratório de Dramaturgismo e Direção rotativa de cenas. Universidade Federal de Pelotas. Outubro/2016.

FERNANDES, Silvia. Teatralidades contemporâneas. São Paulo: Perspectiva, 2010.

FREITAS, Angélica. Um útero é do tamanho de um punho. São Paulo: Cosac Naify, 2013.

GUTIERREZ, Ester J. B. Negros, charqueadas e olarias: um estudo sobre o espaço pelotense. Pelotas: Ed. Universitária/UFPel, 2001.

KOLTĖS, Bernard-Marie. Combate de negro e de cães; O retorno ao deserto; Tabataba. Ed. bilíngue. Trad. Ângela Leite Lopes. São Paulo: Aliança Francesa/Instituto Totem Cultural/Imprensa Oficial do Estado de São Paulo, 2010.

PAVIS, Patrice. Dicionário de teatro. 2a ed. São Paulo: Perspectiva, 2003. 


\section{Urdimento}

PICON-VALLIN, Béatrice. O Théâtre du Soleil: os primeiros cinquenta anos. São Paulo: Perspectiva: SESC São Paulo, 2017.

Recebido em: 26/06/2020

Aprovado em: 02/10/2020 